\title{
GREEN MARKETING ORIENTATION AND ENVIRONMENTAL AND SOCIAL PERFORMANCE OF HOSPITALITY FIRMS IN SOUTH AFRICA
}

\author{
Olawale FATOKI \\ University of Limpopo, Department of Business Management, Polokwane, SOUTH AFRICA \\ e-mail: olawale.fatoki@ul.ac.za
}

\begin{abstract}
The pressure on businesses to engage not only on profitability but also on social and environmental responsibility has increased in recent times. The study empirically tested the relationship between green marketing orientation (GMO) and environmental and social performance in the context of firms in the hospitality industry. Sustainable performance measurement focuses not only on financial but also on social and environmental performance. The study used the quantitative research design, and the cross-sectional survey method was used for data collection from 192 respondents. Descriptive statistics, Pearson correlation, and regression analysis were used for data analysis. Cronbach's alpha was used as a measure of reliability. The results indicated a significant positive relationship between GMO and environmental and social performance of hospitality firms. The findings of the study suggest that GMO is a firm-level strategic resource that can improve the sustainable performance of firms in the hospitality sector. Theoretically, the study linked GMO to environmental and social performance of firms. Empirically, the study adds to the literature on the effect of GMO on sustainable performance. Practically, the study suggested recommendations that can improve the adoption of GMO by firms. These include green design, green positioning, green supply chain, and green strategy.
\end{abstract}

Keywords: green marketing orientation, environmental, social, performance, hospitality, tourism, South Africa.

JEL: M10, M13, M14, M31.

\section{Introduction}

Sustainable development is based on three fundamental pillars. These are economic growth, social equity, and environmental protection. Sustainable development is on the agenda of the majority of the countries in the world. The 2030 agenda for sustainable development and its 17 sustainable development goals were adopted by most of the countries in the world in 2015. The agenda as a plan of action focuses on people, prosperity, and the planet. The people side of the agenda focuses on ending hunger and poverty and ensuring equality and dignity for all human beings. Prosperity aims to ensure that all human beings enjoy prosperous and fulfilling lives. The goal of the planet side of the agenda is to protect the planet from degradation. This will be achieved through the sustainable management of the world's natural resources and sustainable production and consumption (goal 12) (United Nations, 2016, Nygard, 2017; Georgeson, et al., 2017).
Businesses, customers, and government are some of the primary stakeholders of sustainable development. The pressure on businesses to engage not only on profitability but also on social and environmental responsibility has increased in recent times. The traditional explanation of value creation as purely measured by economic profit has extended to include non-economic gains. Sustainable entrepreneurship allows businesses to be profitable while also focusing on environmental and social challenges (Sarango-Lalangui, et al., 2018; Nhemachema and Murimbika, 2018). The concept of shared values by Porter and Kramer (2011) contends that businesses should take into consideration economic and societal progress. Environmental challenges have grown worldwide as can be evidenced by the negative effects of climate change. This has created societal awareness about the negative impact of business activities on the environment (Chen, et al., 2015; Fadhilah and Andriyansah, 2017). In addition, customers are becoming more environmentally conscious and are paying attention to environmental 
products and services. This has changed the competitive landscape and stimulated the demand for sustainable production and consumption. The objectives of sustainable production include the responsible and sustained use of natural resources, energy efficiency and the reduction of waste and pollution. Sustainable consumption is the consumption of goods and services that are economically viable, socially equitable, and with minimal impact upon the environment. Sustainable consumption is generally tied to the retailer and consumer end of the value chain (Camilleri, 2018; Vantamay, 2018).

One of the ways to ensure sustainable production and consumption and ultimately sustainable development is for businesses to have a sustainable or green marketing orientation (GMO). GMO is an extension of marketing orientation (MO) which is a firmspecific intangible resource that can help businesses to realize value. MO allows a firm to obtain information about customers, suppliers, and technological and environmental trends (Wang, 2015; Chen, et al., 2015). GMO is a business strategy that enables firms to develop and promote environmentally friendly good and services that are valued by customers. GMO is a strategic resource that can provide firms with a sustainable competitive advantage. Sustainability is a major concern for marketing and sustainability-oriented marketing strategy is inextricably linked to the future of the natural environment. GMO ensures that customers' needs are met, organizational goals are attained, and the process ensures social equity and the protection of the natural environment. GMO broadens the scope of corporate coalitionbuilding beyond immediate market and financial stakeholders, enhances firm reputation, and improves community support and employee commitment (Mitchell, et al., 2010; Hult, 2011; Crittenden, et al., 2011; Pantelic, et al., 2016).

The performance of a firm's marketing strategy and sustainability initiatives needs to be evaluated. Performance measures include financial and nonfinancial indicators (Eneizan and Wahab, 2016). Non-financial performance measures have been receiving increasing attention in recent years as modern organizations seek to provide additional information to managers to make strategic decisions. Inadequacies of the financial performance measure, especially its focus on short-term profitability, have led to innovation in performance measurement ranging from non-financial indicators to the balanced scorecard to integrated performance measures. Sustainable or triple bottom line measures of performance focus not only on financial but also on social and environmental performance (Ahmad and Sabri, 2016; Elkington, 2018). Extant studies on GMO have focused mainly on financial measures and market capability (Amegbe, et al., 2017). The effects of GMO on non-financial metrics have been largely unexplored. Based on this gap in the literature, the aim of the study is to examine the relationship between GMO and environmental and social performance of the firm in the context of the hospitality sector. This study is significant as the tourism industry is slowly changing priorities from pure economic considerations to a sustainable tourism marketing model (Aimagambetov, et al., 2017; Kisi, 2019). This study will make an empirical contribution to the literature on the nexus between GMO and environmental and social performance in the context of the hospitality industry. The study is organized as follows: the next section provides a review of the literature on tourism and hospitality, performance, and GMO. Then, the research methodology, results, discussion, and conclusion are presented.

\section{Literature review}

\subsection{Tourism and hospitality industry}

The hospitality industry is an extensive category of fields within the tourism industry. There is no agreement about the definition of tourism because of its multidisciplinary nature ( $\mathrm{Yu}$, et al., 2012). The United Nations World Tourism Organization (2010) points out that tourism "comprises the activities of persons traveling to and staying in places outside their usual environment for not more than one consecutive year for leisure, business and other purposes".. Tourism-related activities include accommodation, food and beverage services, recreation and entertainment, and transportation and travel services. The hospitality industry is the largest segment of the tourism industry (United Nations World Tourism Organization, 2008). Just like tourism, there is 
no consensus on the definition of hospitality (Hemmington, 2007; Ottenbacher, et al., 2009).

The Department of Labour of South Africa (2016) describes hospitality as a commercial business involved in the provision of accommodation. The hospitality sector includes hotels, motels, lodges, guest houses including bed and breakfast establishments, restaurants, pubs, taverns, and cafés. Golubovskaya, et al. (2017) remark that hospitality can be examined from three domains which are private, social, and commercial. Private hospitality relates to private homes where guests are welcomed by hosts without explicit financial motives. Social hospitality focuses on the provision of hospitality artifacts that are connected to cultural norms and traditions. Commercial hospitality is profit-driven. The goal of commercial hospitality is to provide pleasure and satisfaction to guests to enable their repeat visitation. The hospitality industry contributes significantly to employment creation and economic growth of South Africa. The broad tourism industry including hospitality contributed $8.2 \%$ of total investment, $9.6 \%$ of total employment, and $8.9 \%$ of South Africa's gross domestic product in 2017 (World Travel and Tourism Council, 2018). Despite the positive contribution of the hospitality industry, its negative impacts include the production and emissions of greenhouse gases, high water, and energy consumption. This has led to the demand by customers and governments for a green or sustainable hospitality. Green hospitality embraces sustainability as a major component of the business model (Mbasera, et al., 2016).

\subsection{Green business, products, and customers}

Environmental protection and social equity are becoming very important to businesses and customers. A green business integrates the principles of sustainability into its business operations and influences consumption patterns by supplying environmentally friendly products and services. Adapting the definition of sustainable development, a green business "meets the needs of the present [world] without compromising the ability of future generations to meet their own needs" (Karagülle, 2012; Andersen and Faria, 2015). A green business is "a firm that is committed to the principles of environmental sus- tainability in its operations, strives to use renewable resources, and tries to minimize the negative environmental impact of its activities" (Čekanavičius, et al., 2014, p.76). A green business is expected to produce green products and services. Green products and services can be described as products with eco-friendly production process that leads to minimal damage to the environment. The raw material used, product design, production, and packaging must be eco-friendly (Arseculeratne and Yazdanifard, 2014; Eneizan and Wahab, 2016). A green customer is an individual or a firm that is concerned about the environment, exhibits environmentally conscious behavior, and purchases environmentally friendly products (Ansar, 2013; Diglel and Yazdanifard, 2014).

\section{$2.3 \quad$ GMO}

One of the primary goals of marketing is to influence customer purchasing decisions. Marketing apart from promoting and selling goods and services also aims to educate and influence society. The term "green marketing" is also referred to as "sustainable marketing", "ecological marketing", or "environmental marketing. Green marketing was first used in the late 1970 s and came into prominence in the late 1980s and early 1990s (Yan andYazdanifard, 2014). Green marketing is one of the most important areas of focus for the firm and society especially in this era of sustainable development. Charter and Polonsky $(1999$, p.6) point out that "green marketing is the marketing or promotion of a product based on its environmental performance or an improvement thereof". Green marketing is similar to traditional marketing but incorporates marketing activities that involve the manufacturing, pricing, and promotion of goods and services that are environmentally friendly to satisfy the environmental needs of customers. The need for green marketing has increased as environmental issues facing the world have become more evident. Marketers have embraced green marketing as a source of competitive advantage. Green marketing can influence consumption patterns and change production systems. Through green marketing, a firm can achieve profitability by applying economically, environmentally, and socially responsible value systems (Mitchell, 
et al., 2010; Boztepe, 2012; Govender and Govender, 2016; Pantelic, et al., 2016).

GMO links MO to sustainability. Narver and Slater (1990) in a seminal paper define MO as a business culture that leads to superior customer value creation through three components: customer orientation, competitor orientation, and interfunctional orientation. Jaworski and Kohli (1993, p.54) define MO as "organization-wide generation of market intelligence pertaining to current and future needs of customers, dissemination of intelligence horizontally and vertically within the organization and organization wide action or responsiveness to market intelligence". Woodalla and Swailes (2009) describe MO as how an organization obtains and uses information from customers to develop and implement a strategy that meets customer needs and wants. GMO is a synthesis of MO, macromarketing, and sustainable development management concepts. GMO is a new systematic approach to marketing management that ensures value to different stakeholders. Apart from the market place, embracing a GMO perspective brings about a greater appreciation of environmental and societal challenges. GMO allows corporate management to move beyond the conventional focus on microeconomic and functional management prescribed by MO (Mitchell, et al., 2010; Papadas, et al., 2017). Mitchell (2012, p.3) defines GMO as a "mechanism that seeks to help manage marketoriented activity while minimising adverse impacts on the environment".

The Stakeholder theory and the Natural-Resource Based View (NRBV), an extension of the Resource Based View (RBV) of the firm, can be used to provide the theoretical justification for GMO. The Stakeholder Theory by Freeman (1984) defines stakeholders as an organization or individual whose activities are affected either by the firm or the way the firm operates. Stakeholders include employees, investors, customers, suppliers, and the environment. The new concept in marketing is stakeholder marketing, and this has established the support for redefining and broadening the marketing discipline. Stakeholder marketing can be described as processes and activities that facilitate and maintain value through exchange relationships with multiple stakeholders (Hult, et al., 2011). According to Gonzalez-
Padron (2016), stakeholder marketing takes into consideration social and environmental stakeholders and can be positively linked to organizational outcomes such as customer satisfaction, reputation, and innovation. In addition, based on ResourceAdvantage theory, Crittenden, et al. (2011) developed the market-oriented sustainability framework that incorporates sustainability into market orientation in order to achieve competitive advantage. The framework includes three constructs which are the DNA, stakeholder involvement, and performance management. DNA is a metaphor used to capture the workings of an organization and how it can implement sustainability. The DNA is communicated to both internal and external stakeholders, thus, ensuring their involvement. Performance measures environmental social and financial indicators. The RBV by Barney $(1986,1991)$ contends that valuable firm resources and capabilities are the key sources of sustainable competitive advantage for a firm. GMO is an important firm-level strategic organizational orientation that takes into consideration the environment. The NRBV by Hart (1995) argues that the competitive advantage of a firm is based on its relationship with the natural environment. This relationship can be improved by GMO.

\subsection{Performance}

Firm performance does not have a universally accepted definition. Despite its relevance, there is scarcely any consensus about its definition, dimensionality, and measurement. The definitions of performance focus on the effectiveness or success of a firm, employee performance, ability to create value for customers, productivity, flexibility and adaptability, the achievement of goals, and stakeholder satisfaction (Selvam, et al., 2016; Taouab and Issor, 2019). Lebans and Euske (2006) define firm performance as a set of financial and non-financial indicators that provide information on the accomplishment of objectives and results. The financial framework is the oldest paradigm for performance measure and has its foundation in the areas of accounting, financial management, and economics. Financial or objective performance includes the following: (1) Profitability indicators such as the return on assets, gross profit margin, operational profit 
margin, return on investment, net income, return on equity, and economic value added (EVA); (2) market value indicators: these include earnings per share, change in share price, and Tobin's Q; (3) Growth performance such as market-share growth, asset growth, net revenue growth, and net income growth (Marie, et al., 2014; Selvam, et al., 2016). Despite the importance of financial measures, they are not an adequate performance measurement system. Financial indicators have a strategic short-term orientation. Firm value is created through different activities such as innovation, quality customer, and employee satisfaction, and financial indicators alone are unlikely to measure and fully reflect the long-term consequences of these activities. Also, financial measures are usually lagging measures of performance, while non-financial measures are leading measures of performance that provide insight about future performance (Briggs, et al., 2006; Marie, et al., 2014; Ahmad and Sabri, 2016). Non-financial or subjective performance measures include employee satisfaction (employee turnover, investments in employees development and training, and organizational climate), customer satisfaction (number of complaints, repurchase rate, customer retention), environmental performance (recycling, material usage, energy consumption, pollution, and waste), and social performance (employment of minorities, contribution to social causes) (Selvam, et al., 2016; Taouab and Issor, 2019). Businesses are a major part of sustainable development. For a business, sustainable development means implementing business strategies and activities that meet the needs of the enterprise and its stakeholders today while protecting the human and natural resources. The sustainable approach or triple bottom line to measuring business performance focuses not only financial but also social and environmental performance (Elkington, 2018). The balanced scorecard (BSC) measure of performance captures the financial and nonfinancial metrics and focuses on four perspectives: financial, customer, internal process and learning, and growth (Kaplan and Norton, 1992). This study focuses on the environmental and social performance. Environmental performance is important to firms for several reasons. First, firms are increasingly being responsible for their environmental actions and behavior as can be evidenced by the growing number of penalties, laws, and regulations. Second, environmental performance measure helps to ensure the attainment of environmental objectives and to allocate limited resources to improve firm environmental behavior. Third, environmental performance is one of the ways to improve business practices and firm performance (Selvan, et al., 2016). Social performance emphasizes a firm's responsibilities to multiple stakeholders, such as employees and the community and helps a firm to achieve its social goals (Chen and Dalmas, 2011).

\subsection{GMO and environmental performance}

The relationship between market orientation and environmental performance of the firm is unclear. Market orientation is an important function that can help a firm to develop and promote environmentally friendly goods and services that are valued by customers. A strong market orientation promotes environmental sustainability efforts by creating management awareness of customer demands for eco-friendly products and services (Crittenden, et al., 2011; Chen, et al., 2015). Green, et al. (2015) examine whether market orientation supports green supply chain management practices and improved environmental performance. Included in green supply chain management practices are green purchasing, cooperation with customers, and eco-design. The findings show that market orientation, both directly and indirectly (through green supply chain management practices), positively impacts environmental performance. Yan and Yazdanifard (2013) point out that one of the disadvantages of green business orientation is that the business is only concerned about the purchasing of green products and not the domain of product usage. Environmentally conscious consumers are more likely to perceive a negative relationship between green products and their effectiveness. This suggests that environmentally conscious consumers are more likely to overuse green products than less environmentally conscious customers. The overuse leads to unnecessary waste and a costly consequence on the environment. The effect of GMO on environmental performance remains largely unexplored. However, GMO helps to facilitate sustainable production, marketing, and consumption. The objectives of sustainable produc- 
tion and consumption include the responsible and sustained use of natural resources, energy efficiency, and the reduction of waste and pollution. It is hypothesized (H1) that there is a significant positive relationship between GMO and environmental performance.

\subsection{GMO and social performance}

Empirical studies largely support a positive relationship between MO and internal and external social responsibility. Internal corporate social responsibility relates to the psychological and physical working environment of employees. External social responsibility focuses on the local community, suppliers, customers, government, and non-governmental organizations (Turker, 2009; Mahmoud, et al., 2017). Hwang and Chung (2017) find that the three components of market orientation (customer orientation, competitor orientation, and interfunctional coordination) significantly and positively impact the firm's corporate social responsibility involvement. MO enhances the firm's performance indirectly through employee job satisfaction and customer satisfaction with product quality (Zhou, et al., 2008; Altarifi, et al., 2016). Green marketing practices can lead to customer satisfaction and provide employees with a healthy and safe work environment. Green marketing can help a firm to develop social responsibility toward the environment and community (Prinzing, 2013; Čekanavičius, et al., 2014; Eneizan and Wahab, 2016). Consequently, it is hypothesized (H2) that there is a significant positive relationship between GMO and social performance.

\section{$3 \quad$ Research methodology}

The study utilized the quantitative research method with descriptive and causal research designs that were used to analyze and test the relationship between the variables of the study. The cross-sectional survey technique through the self-administered questionnaire method was used for data collection.

The population for the study is all hotels in South Africa. The convenience sampling method was used for the study because the hotels were selected from a variety of accommodation databases. The data- bases used to identify the sample of the study included the Johannesburg Accommodation listing, Tshwane Accommodation listing, Centurion Bed and Breakfast Association, Guesthouse Association of Tshwane, and the Tourism Grading Association of South Africa. The study focused on formal service accommodation (hotel and lodges) and guest accommodation (Bed and Breakfast, Country house and Guesthouse) (Tourism Grading Association of South Africa, 2018).

Five hundred questionnaires were sent out physically to the respondents. Three well-trained data collectors assisted the researcher in the data collection process. Managers or owners were the identified respondents because they were more likely to have the required information about the MO and sustainable performance of their firms. The phone numbers and email addresses of the respondents were obtained during the distribution of questionnaires. Reminders were sent to the respondents every week through emails and phone calls to complete the questionnaire. If questionnaires were not received after 1 week, a follow-up procedure included telephone calls and email reminders every week. If no response is received after 6 weeks, it is treated as non-response. This effort led to the collection of 192 completed and usable questionnaires.

Before data collection, the questionnaire was pretested in a pilot study of 30 respondents. The results of the pretesting helped to restructure some questions, remove unclear and sensitive questions, and improve face and content validity. The participants were informed about the aim of the study and that participation was voluntary. The participants assured confidentiality. This information was contained in the cover page of the questionnaire. To ensure anonymity, the names of the participants and their organizations were not included in the questionnaire. Cronbach's alpha was used as a measure of reliability. Descriptive statistics, Pearson correlation, and regression analysis were used for data analysis.

\section{$4 \quad$ Measures}

The questionnaire was divided into three parts: biographical details, GMO, and environmental and social performance. 


\subsection{GMO}

Ten questions adapted from the market orientation scale developed by Deshpande and Farley (1998) and anchored on the five-point Likert scale with "1 strongly disagree and 5 strongly agree" were used to measure GMO. The items were as follows: (1) Our green business objectives are driven primarily by customer satisfaction; (2) We constantly monitor our level of commitment and orientation to serving the green needs of our customers; (3) We freely communicate green products and services to our customers and employees; (4) Our strategy for competitive advantage includes the understanding of the green needs of our customers; (5) We frequently measure customer satisfaction with our green products and services; (6) We measure customer service on a regular basis; (7) Compared with our competitors, we have invested more in green products and services that meet the needs of our customers; (8) We believe this business exists primarily to serve customers including green customers; (9) We poll customers at least once a year to assess the quality of our green products and services; (10) Data on customer satisfaction with our products and services including green products are disseminated at all levels in this business unit on a regular basis.

\subsection{Environmental performance}

Five variables anchored on the five-point Likert scale with " 1 strongly disagree and 5 strongly agree" were used to measure environmental performance. These were: (1) improved efficiency of raw materi- als; (2) reduced resource consumption (energy and water); (3) increased recycling of materials; (4) reduction in the cost of environmental compliance, and (5) increased overall reputation in respects of products and services. The variables were adapted from previous empirical studies on environmental performance (Qorri, et al., 2018; Magsi, et al., 2018).

\subsection{Social performance}

Five variables focusing on both internal and external social responsibility and anchored on the five-point Likert scale with " 1 strongly disagree and 5 strongly agree" were used to measure social performance. The variables were: (1) increased customer satisfaction with products and services; (2) reduced staff turnover; (3) increased employee satisfaction; (4) increased employee health and safety, and (5) increased contribution to the local community for social issues. The variables were adapted from previous empirical studies on social performance (Rashid, et al., 2015; Hernandez-Perlines and Cisneros, 2017).

\section{Results}

\subsection{Response rate and biographical information}

During the data collection process, 500 questionnaires were distributed to owners and managers of hospitality firms and 192 questionnaires were returned and found usable. Table 1 shows the biographical details of the respondents.

Table 1. Biographical details of the respondents

(Source: Author's own research)

\begin{tabular}{|l|c|}
\hline \multicolumn{1}{|c|}{ Biographical characteristics } & Frequency $(\mathrm{N}=192)$ \\
\hline Educational qualification of respondents & 0 \\
\hline Below matric & 45 \\
\hline Matric & 147 \\
\hline Post-matric qualifications & 72 \\
\hline Gender of the respondents & 120 \\
\hline Female & \\
\hline Male &
\end{tabular}


Table 1. Biographical details of the respondents (cont.)

(Source: Author's own research)

\begin{tabular}{|c|c|}
\hline Age of the respondents (years) \\
\hline Less than 20 & 0 \\
\hline $20-30$ & 7 \\
\hline $31-40$ & 59 \\
\hline $41-50$ & 73 \\
\hline Above 50 & 53 \\
\hline Age of the firm (years) & \\
\hline Less than one & 0 \\
\hline $1-5$ & 36 \\
\hline $6-10$ & 104 \\
\hline Above 10 years & 52 \\
\hline Number of employees & \\
\hline No employees & 0 \\
\hline $1-5$ employees & 0 \\
\hline $6-20$ employees & 33 \\
\hline $21-50$ employees & 89 \\
\hline $51-200$ employees & 70 \\
\hline
\end{tabular}

According to Table 1, the majority of the respondents of the survey are male with post-matric qualification, with 6-10 years of operation and between 21 and 50 employees. The majority of the responding firms can be categorized as small and medium enterprises according to the Schedule of Size Standards for the classification of small and medium enterprises in South Africa (Government Gazette, 2003).

\subsection{Descriptive statistics, correlational analysis, and reliability}

Table 2 shows the descriptive statistics using the scale means and the Pearson correlation coefficient for each factor. The mean score for GMO is 3.155 with a standard deviation of 1.014. Environmental performance has the highest score (mean 3.355; SD 0.997).

Table 2. Descriptive statistics, Pearson correlation, and reliability (Source: Author's own research)

\begin{tabular}{|l|l|l|l|c|c|}
\hline & Variable & SD & 1 & 2 & 3 \\
\hline GMO & 3.155 & 1.014 & 1.000 & - & - \\
\hline EP & 3.355 & 0.997 & $0.674^{*}$ & 1.000 & - \\
\hline SP & 3.190 & 1.001 & 0.618 & $0.666^{* *}$ & 1.000 \\
\hline $\begin{array}{l}* \mathrm{P}<0.001 ; * * \mathrm{P}<0.05 \\
\text { EP - environmental performance, GMO - green marketing orientation, SD - standard deviation, } \\
\text { SP - social performance }\end{array}$ \\
\hline
\end{tabular}

This is followed by the social performance (mean 3.190, SD 1.001). On a five-point Likert scale, a mean value below 3 is considered as low, 3-4 moderate and above 4 high (Neneh and van Zyl, 2017). 
The results indicate a moderate level of GMO and environmental and social performance by hospitality firms.

The results of the correlation show that GMO is significantly associated with environmental performance $(\mathrm{r}=0.674 ; \mathrm{P}<0.001)$ and social performance $(\mathrm{r}=0.666, \mathrm{P}<0.005)$. Cronbach's alpha was used as a measure of reliability. Cronbach's alpha coefficients for GMO, environmental performance, and social performance are $0.77,0.81$, and 0.79 , respectively, indicating the internal consistency of measures. Nunnaly (1978) suggests that the Cronbach's alpha coefficients greater than 0.70 are acceptable.

\subsection{Regression results}

Tables 3 and 4 show the regression results of GMO and EP and GMO and SP.

Table 3. Regression results of GMO and EP (Source: Author's own research)

\begin{tabular}{|l|c|c|c|c|c|}
\hline \multirow{2}{*}{ Model } & \multicolumn{2}{|c|}{ Unstandardized coefficients } & $\begin{array}{c}\text { Standardized } \\
\text { coefficients }\end{array}$ & \multirow{2}{*}{$\mathrm{T}$} & Significance \\
\cline { 2 - 5 } & $\mathrm{B}$ & $\mathrm{SE}$ & Beta & 2.153 & 0.001 \\
\hline Constant & 101.247 & 3.118 & - & 11.164 & 0.001 \\
\hline $\mathrm{EP}$ & 1.141 & 0.583 & 0.637 & \\
\hline $\begin{array}{l}\mathrm{N}=192, \mathrm{R}=0.631, \mathrm{R} \text { square }=0.653, \text { adjusted R square }=0.679, \text { significance }<0.05, \\
\mathrm{EP}-\text { environmental performance, GMO }- \text { green marketing orientation, SE }- \text { standard error }\end{array}$ \\
\hline
\end{tabular}

Table 4. Regression results of GMO and SP (Source: Author's own research)

\begin{tabular}{|l|c|c|c|c|c|}
\hline \multirow{2}{*}{ Model } & \multicolumn{2}{|c|}{ Unstandardized coefficients } & $\begin{array}{c}\text { Standardized } \\
\text { coefficients }\end{array}$ & \multirow{2}{*}{$\mathrm{T}$} & Significance \\
\cline { 2 - 5 } & $\mathrm{B}$ & $\mathrm{SE}$ & Beta & 1.319 & 0.001 \\
\hline Constant & 102.074 & 3.225 & - & 10.217 & 0.001 \\
\hline $\mathrm{SP}$ & 1.093 & 0.603 & 0.618 & \\
\hline $\begin{array}{l}\mathrm{N}=192, \mathrm{R}=0.618, \mathrm{R} \text { square }=0.626, \text { adjusted R square }=0.628, \text { significance }<0.05, \\
\text { GMO }- \text { green marketing orientation, SE }- \text { standard error, SP }- \text { social performance }\end{array}$ \\
\hline
\end{tabular}

The normality of the data was measured by examining the normal probability-probability plot. The data formed a straight line along the diagonal, and thus normality can be assumed. To assess homoscedasticity, a scatterplot of standardized residuals versus standardized predicted values was created. The plot shows random scatter, and thus the assumption is met.

Multicollinearity was assessed by calculated variance inflation factors (VIFs). The VIFs were less than 6 suggesting that multicollinearity can be assumed. The results of the regression model indicate that there is a significant positive relationship between GMO and environmental performance $(\beta=$
$0.637, \mathrm{p}<0.01)$ and GMO and social performance $(\beta=0.618, \mathrm{p}<0.01)$.

The first hypothesis (H1) proposed that there is a significant positive relationship between GMO and environmental performance. Based on the results of the correlation and regression, the hypothesis is not rejected.

The second hypothesis (H2) proposed that there is a significant positive relationship between GMO and social performance. Based on the results of the correlation and regression, the hypothesis is not rejected. Thus, it can be concluded that GMO positively influences the environmental and social performance of firms in the hospitality sector. 
6

\section{Discussion}

The pressure on businesses to engage not only on profitability but also on social and environmental responsibility has increased in recent times. Customers are becoming more environmentally conscious and are paying attention to environmental products and services. This has changed the competitive landscape and stimulated the demand for sustainable production and consumption. GMO is a business strategy that enables firms to develop and promote environmentally friendly good and services that are valued by customers Sustainability is a major concern for marketing and sustainability-oriented marketing strategy is inextricably linked to the future of the natural environment.

The theoretical foundation of the study can be linked to the Stakeholder theory, the Resource-Based theory, the Natural Resource Based theory, and the market-oriented sustainability framework. GMO is a firm-specific intangible resource that can help businesses to realize value. In addition, GMO incorporates both internal and external stakeholders in strategic decisions. Stakeholder marketing takes into consideration social and environmental stakeholders and can be positively linked to organizational outcomes such as customer satisfaction, reputation, and innovation. Market-oriented sustainability framework incorporates sustainability into market orientation in order to achieve a competitive advantage.

The aim of the study was to investigate the relationship between GMO and environmental and social performance of firms in the hospitality sector in South Africa. The study focused on non-financial measures of performance. The results indicated that there is a significant positive relationship between GMO and environmental performance. Crittenden, et al. (2011), Chen, et al. (2015), and Green, et al. (2015) point out that a strong market orientation promotes environmental sustainability efforts by creating management awareness of customer demands for eco-friendly products and services. The findings of the study confirm that GMO is an intangible firm-specific resource that can affect environmental performance.

In addition, the results indicated that there is a significant positive relationship between GMO and social performance. The findings are consistent with Hwang and Chung (2017) that market orientation positively impacts the firm's corporate social responsibility involvement. Zhou, et al. (2008) and Altarifi, et al. (2016) find that MO enhances the firm's performance indirectly through employee job satisfaction and customer satisfaction with product quality. Prinzing (2013), Čekanavičius, et al. (2014), and Eneizan and Wahab (2016) remark that green marketing practices can lead to employee and customer satisfaction and can help a firm to develop social responsibility toward the environment and community.

\section{Conclusion}

Environmental protection and social equity are becoming very important to businesses and customers. A green business integrates the principles of sustainability into its business operations and also changes consumption patterns by supplying environmentally friendly products and services. The study investigated the relationship between GMO and environmental and social performance of firms in the hospitality business. The findings indicated a significant positive relationship between GMO and environmental and social performance.

The findings of the study indicated that GMO can improve the non-financial performance of hospitality firms. The theoretical implication of the study is the linkage of GMO to non-financial measures of performance. Extant studies on GMO have focused mainly on financial measures and the effects of GMO on non-financial metrics have been largely unexplored. Empirically, the study adds to the literature on the effect of GMO on sustainable performance.

A thorough review of the literature by the researcher revealed that this is the first study in South Africa to link GMO to environmental and social performance. Practically, the findings of the study could help the hospitality sector to improve environmental sustainability. Green marketing should be incorporated into the operational and strategic plans of hospitality firms. This includes green design, green positioning, green pricing, green supply chain, and green positioning. To ensure green design, 
the conceptualization of products and services must be environmentally friendly. Hotels must embrace green construction and green buildings. To improve green marketing, firms must incorporate green supply chain and green consumption throughout the life cycle. Green positioning means that promotions and advertisements by hospitality firms should include sustainability. Green facilities such as recycle bins must be available in hotels. Hospitality firms through their executives and employees must have clear environmental missions and visions. Firms must be up to speed about new developments in the areas of climate change, clean technology, and green consumer behavior. Training to improve sustainability by hospitality firms should include GMO.

The promotion of social sustainability, especially employee and customer satisfaction, and community responsibility should include GMO. The study has some limitations. Convenience sampling was used to draw the sample of this study. This sampling method suffers from sampling bias and that the sample is not representative of the entire population. Also, only 192 hospitality firms participated in the study. Thus, care should be exercised in generalizing the findings of the study. Other studies can examine the effect of GMO on other measures of performance such as quality and innovation performance. Also, a longitudinal study on the effect of GMO on sustainable performance measures will improve the cause and effect relationship.

\section{References}

[1] Ahmad, K., Sabri, S., 2016. The Effect of Nonfinancial Performance Measurement System on Firm Performance. International Journal of Economics and Financial Issues, 6(S6), pp.50-54.

[2] Aimagambetov, E., Bugubaeva, R., Bespayeva, R.,Tashbaev, N., 2017. Model of Sustainable Development of Tourism Industry in Kazakhstan (regional perspective). Public Policy and Administration, 16(2), pp.179-197.

[3] Altarifi, S.M., Aqe, I.,Tarawneh, K.A., 2016. The Impact of Market Orientation on Customer Satisfaction of Private Schools in Jordan. International Journal of Business and Management 11(9), pp.117-125.
[4] Amegbe, H., Owino, J., Nuwasiima, A., 2017. Green Marketing Orientation (GMO) and Performance of SMEs in Ghana. American Journal of Management, 11(1), pp.99-109.

[5] Andersen, M.M., Faria, L., 2015. The Green Economy and Emerging Green Business Models in the Danish Window Industry. Paper presented at 18th International Conference on Sustainable Innovation, Epsom, United Kingdom.

[6] Ansar, N., 2013. Impact of Green Marketing on Consumer Purchase Intention. Mediterranean Journal of Social Science, 4 (11), pp.23-45.

[7] Arseculeratne, D.,Yazdanifard, R., 2014. How Green Marketing Can Create a Sustainable Competitive Advantage for a Business. International Business Research,7, pp.130-137.

[8] Barney, J.B., 1986. Organizational Culture: Can it be a Source of Sustained Competitive Advantage. Academy of Management Review, 11, pp.656-665.

[9] Barney, J.B., 1991. Firm Resources and Sustained Competitive Advantage. Journal of Management, 17, pp.99-120.

[10] Boztepe, A., 2012. Green Marketing and Its Impact on Consumer Buying Behaviour. European Journal of Economic and Political Studies, 5(1), pp.5-21.

[11] Briggs, J., Claiboborne, M.C., Cole, E., 2006. Total Optimal Performance Scores: a Practical Guide for Integrating Financial and Nonfinancial Measures in Performance Evaluation. Management Accounting Quarterly, 8(1), pp.11-23.

[12] Camilleri, M.A., 2018. Closing the Loop for Resource Efficiency, Sustainable Consumption and Production: A Critical Review of the Circular Economy. International Journal of Sustainable Development, 1, pp.1-22.

[13] Čekanavičius, L., Bazytè, R., Dičmonaitè, A., 2014. Green Business: Challenges and Practices. Ekonomika, 93(1), pp.74-88.

[14] Charter, M., Polonsky, M.J., 1999. Green Marketing: A Global Perspective on Green Marketing Practices. Sheffield: Greenleaf Publication.

[15] Chen, C., Dalmas, M., 2011. Measuring Corporate Social Performance: An Efficiency Perspective. Production and Operations Management, 20(6), pp.789-804

[16] Chen, Y., Tang, G., Jin, J., Li, J., Paillé, P., 2015. Linking Market Orientation and Environ- 
mental Performance: The Influence of Environmental Strategy, Employee's Environmental Involvement, and Environmental Product Quality. Journal of Business Ethics, 127(2), pp.479-500.

[17] Crittenden, V., Crittenden, M., Ferrell, L., Ferrell, O., 2011. Market-oriented Sustainability: A Conceptual Framework and Propositions. Journal of the Academy of Marketing Science, 39(1), pp.71-85.

[18] Deshpande, R., Farley, J., 1998. Measuring Market Orientation: Generalization and Synthesis. Journal of Market-Focused Management, 2(3), pp.213-232

[19] Diglel, A., Yazdanifard, R., 2014. Green Marketing and its Influence on Buying Behaviour and the Attitudes of Purchasers towards Ecofriendly products. Global Journal of Management and Business Research,7(11), pp.11-18.

[20] Elkington, J., 2018. 25 Years Ago I Coined the Phrase "Triple Bottom Line." Here's Why It's Time to Rethink It", [online] Harvard Business Review, Available at: https://hbr.org/2018/06/25years-ago-i-coined-the-phrase-triple-bottom-line -heres-why-im-giving-up-on-it [Accessed 20 April, 2019].

[21] Eneizan, B.M., Wahab, K.A., 2016. Effects of Green Marketing Strategy on the Financial and Non-Financial Performance of Firms: A Conceptual Paper. Arabian Journal Business Management Review, 6(5), pp.1-7.

[22] Fadhilah, M., Andriyansah, 2017. Strategic Implementation of Environmentally Friendly Innovation of Small and Medium-Sized Enterprises in Indonesia. European Research Studies Journal, 20(4), pp.134-148.

[23] Fraj, E., Martınez, E., Matute, J., 2011. Green Marketing Strategy and the Firm's Performance: the Moderating Role of Environmental Culture. Journal of Strategic Marketing, 19(4), pp.339355.

[24] Goh, Y., Goh, W., Ariffin, S., Salamzadeh, Y., 2019. How Green Marketing Mix Strategies Affects the Firm's Performance: a Malaysian Perspective. International Journal of Sustainable Strategic Management, 7(1/2), pp.1-13.

[25] Govender, J.,Govender, T., 2016. The Influence of Green Marketing on Consumer Purchase Behavior. Environmental Economics, 7(2), pp.7785.
[26] Golubovskaya, M., Robinson, R.,Solnet, D., 2017. The Meaning of Hospitality: do Employees Understand? International Journal of Contemporary Hospitality Management, 29(5), pp.1282-1304.

[27] Georgeson, L., Maslin, M., Poessinouw, M., 2017. The Global Green Economy: a Review of Concepts, Definitions, Measurement Methodologies and their Interactions. Geography and Environment, 4 (1), pp.1-24.

[28] Gonzalez-Padron, T.L, Hult, G.T.M, Ferrell, O.C., 2016. A Stakeholder Marketing Approach to Sustainable Business. Marketing in and for a Sustainable Society, pp.61-101,

[29] Government Gazette of the Republic of South Africa. 2003. National Small Business Amendment Act. [online]. Available: http://www.info. gov.za/gazette/acts/2003/a2603.pdf [Accessed 20 June 2018].

[30] Green, K., Toms, L., Clark, J., 2015. Impact of Market Orientation on Environmental Sustainability Strategy. Management Research Review, 38(2), pp.217-238.

[31] Hart, S.L., 1995. A Natural-Resource-Based View of the Firm. The Academy of Management Review, 20(4), pp.986-1014.

[32] Hau, L.N., Evangelista, F., Thuy, P.N. 2013. Does it Pay for Firms in Asia's Emerging Markets to be Market Oriented? Evidence from Vietnam. Journal of Business Research, 66(12), pp.2412-2417.

[33] Hemmington, N., 2007. From Service to Experience: Understanding and Defining the Hospitality Business. Service Industries Journal, 27(6), pp.747-755.

[34] Hernandez-Perlines, F., Cisneros, M., 2017. Analysis of the Moderating Effect of Entrepreneurial Orientation on the Influence of Social Responsibility on the Performance of Mexican Family Companies. Cogent Business \& Management, 4(1) 1408209.

[35] Hult, T., 2011. Market-focused Sustainability: Market Orientation Plus. Journal of the Academy of Marketing Science, 39, pp.1-6.

[36] Hult, G., Mena, J.A., Ferrell, O.C., Ferrell, L., 2011. Stakeholder Marketing: A Definition and Conceptual Framework. Academy of Marketing Science, 1, pp.44-65. 
[37] Hwang, Y., Chung, S., 2017. Market Orientation, Social Responsibility, and Performance in Korea's Healthcare Industry. International Journal of Healthcare Management, 11(4), pp.325332.

[38] Jaworski, B., Kohli, A., 1993. Market Orientation: Antecedents and Consequences. Journal of Marketing, 57(3), pp.53-70.

[39] Kaplan, R.S., Norton, D.P., 1992. The Balanced Scorecard: Measures that Drive Performance. Harvard Business Review, (January-February), pp.71-79.

[40] Karagülle, A.Ö., 2012. Green Business for Sustainable Development and Competitiveness: An Overview of Turkish Logistics Industry. Procedia Social and Behavioural Sciences, 41, pp.456-460.

[41] Kılıç, S., Özdemir, E., 2018. Green Marketing Strategies and Marketing Performance: The Case of Turkey. In: Driving Green Consumerism Through Strategic Sustainability Marketing. IGI Global

[42] Kisi, N., 2019. A Strategic Approach to Sustainable Tourism Development Using the A'WOT Hybrid Method: A Case Study of Zonguldak, Turkey. Sustainability, 11(4), pp.964-975.

[43] Kohli, A.K., Jaworski B.J., Kumar, A., 1993. MARKOR: A Measure of Market Orientation. Journal of Marketing Research, 30(4), pp.467477.

[44] Lebans, M., Euske, K., 2006. A Conceptual and Operational Delineation of Performance. Business Performance Measurement. Cambridge University Press

[45] Magsi, H., Ong, T., Ho, J., Hassan, A. 2018. Organizational Culture and Environmental Performance. Sustainability, 10(8), pp.2690-2707.

[46] Maletic, M., Maletic, D, Dahlgaard, J., Dahlgaard-Park, S. and Gomiseek, B. 2016. Effect of Sustainability-Oriented Innovation Practices on the Overall Organisational Performance: an Empirical Examination. Total Quality Management and Business Excellence, 9/10, pp.1171-1190.

[47] Mahmoud, M.A., Blankson, C., Hinson, R.F., 2017. Market Orientation and Corporate Social Responsibility: Towards an Integrated Conceptual Framework. International Journal of Corporate Social Responsibility, 2(9), pp.1-15.
[48] Marie, A., Ibrahim, M., Nasser, A., 2014. Effects of Financial and Non-financial Performance Measures on Customers' Perceptions of Service Quality at Islamic Banks in UAE. International Journal of Economics and Finance, 6(10), pp.201-213.

[49] Mbasera, M., Du Plessis, E., Saayman, M., Kruger, M., 2016. Environmentally-friendly Practices in hotels. Acta Commercii, 16(1), a362.

[50] Mitchell, R., Higham, J.,Wooliscroft, B., 2010. Sustainable Market Orientation: A New Approach to Managing Marketing Strategy. Journal of Macromarketing 30(2), pp.160-170.

[51] Mitchell, R., 2012. Sustainable Market Orientation: Its Applicability in Conservation and Tourism Management. [online]. Available: http://cite seerx.ist.psu.edu/viewdoc/download?doi=10.1.1. 853.392\&rep $=$ rep $1 \&$ type $=$ pdf $\quad$ [Accessed 15 March 2019].

[52] Narver, J.C., Slater, S.F., 1990. The Effect of a Market Orientation on Business Profitability. Journal of Marketing, 54(4), pp.20-34.

[53] Nhemachema, C., Murimbika, M., 2018. Motivation of Sustainable Entrepreneurship and their Impact on Enterprise Performance in Gauteng Province, South Africa. Business Strategy and Development, 1, pp.115-127.

[54] Nygard, H.M., 2017. Achieving the Sustainable Development Agenda: The Governance - Conflict Nexus. International Area Studies Review, 20(1), pp.3-18.

[55] Nunnally, J.C., 1978. Psychometric Theory. New York: McGraw-Hill.

[56] Ottenbacher, M., Harrington, R., Parsa, H., 2009. Defining the Hospitality Discipline: A Discussion of Pedagogical and Research Implications. Journal of Hospitality \& Tourism Research, 33(3), pp.263-283.

[57] Papadas, K., Avlonitis, G., Carrigan, M., 2017. Green Marketing Orientation: Conceptualization, Scale Development and Validation. Journal of Business Research, 80, pp.236-246

[58] Pantelic, D., Sakal, M.,Zehetner, A., 2016. Marketing and Sustainability from the Perspective of Future Decision Makers. South African Journal of Business Management, 47(1), pp.37-48.

[59] Pantouvakis, A., Vlachos, I., Zervopoulos, P., 2017. Market Orientation for Sustainable Performance and the Inverted - $U$ moderation 
of firm size: Evidence from the Greek Shipping Industry. Journal of Cleaner Production, 165, pp.705-720.

[60] Porter, M., Kramer, M., 2011. Creating Shared Value. Harvard Business Review, 89(1/2), pp.62-77.

[61] Prinzing, T., 2013. Eco-options Going Green is Getting Easier. Industrial Safety \& Hygiene News, 47(9), pp.46.

[62] Qorri A., Mujkić Z., and Kraslawski A., 2018. A Conceptual Framework for Measuring Sustainability Performance of Supply Chains. Journal of Cleaner Production, pp.1-32

[63] Rashid, N., Khalid, S., Rahman, N., 2015. Environmental Corporate Social Responsibility: Exploring its Influence on Customer Loyalty. Procedia Economics and Finance, 31, pp.705713.

[64] Sarango-Lalangui, P., Santos, J., Hormiga, E., 2018. The Development of Sustainable Entrepreneurship Research Field. Sustainability, 10(6), pp.1-19.

[65] Selvam, M., Gayathri, J.,Vasanth, V., Lingaraja, K., Marxiaoli, S., 2016. Determinants of Firm Performance: A Subjective Model. International Journal of Social Science Studie, 4(7), pp.90100.

[66] United Nations World Tourism Organization, 2008. Tourism highlights. [online]. Available: https://www.e-unwto.org/doi/pdf/10.18111/ 9789284413560 [accessed 15 February, 2019].

[67] The United Nations World Tourism Organization, 2010. Definition of Tourism [online] Available: http://www2.unwto.org/content/about-us-5 [accessed 15 February, 2019].

[68] Turker, D., 2009. How Corporate Social Responsibility Influences Organizational Commitment. Journal of Business Ethics, 89, pp.189204.

[69] United Nations, 2016. About sustainable development goals. [online] Available: https://www. un.org/sustainabledevelopment/sustainable-dev elopment-goals/ [Accessed 15 February, 2019].

[70] Vantamay, N., 2018. Investigation and Recommendations on the Promotion of Sustainable Consumption Behaviour Among Young Con- sumers in Thailand. Kasetsart Journal of Social Science, 39, pp.51-58.

[71] Taouab, O., Issor, Z., 2019. Firm Performance: Definition and Measurement Models. European Scientific Journal, 15(1), pp.93-106.

[72] Thakur, S., 2009. Impact of Green Marketing on Environment and Firm's Performance. Indian Journal of Applied Research. 8(2), pp.5-6.

[73] Wang, C.H., 2015. The Impact of Market Orientation on Innovation Performance: Does Service Innovation Matter? Journal of Business Studies Quarterly, 6(3), pp.77-93.

[74] Woodalla, T., Swailes, S., 2009. Conceptualizing and Measuring Defensive Marketing Orientation (DMO): Some Inaugural Thoughts on Assessing Marketing's Place in Society's Doghouse. Journal of Strategic Marketing, 17(5), pp.345-364.

[75] Wu, S.I., Lin, T.R., 2014. The Influence of Relational Bonds and Innovative Marketing on Consumer Perception - A Study of Theme Parks. Journal of Management and Strategy, 5(4), pp.54-67.

[76] World Travel and Tourism Council, 2018. Travel \& Tourism Economic Impact. South Africa [online]. Available: https://tbcsa.travel/wp-con tent/uploads/2018/03/WTTC-Report-SouthAfri ca2018.pdf [Accessed 16 August, 2018].

[77] Wymer, W., Polonsky, M.J., 2015. The Limitations and Potentialities of Green Marketing. Journal of Nonprofit and Public Sector Marketing, 27, pp.239-262.

[78] Yan, Y.K., Yazdanifard, R., 2014. The Concept of Green Marketing and Green Product Development on Consumer Buying Approach. Global Journal of Commerce and Management Perspective, 3(2), pp.33-38.

[79] Yu, Z., Kim, N., Chen, C., Schwartz, Z., 2012. Are you a Tourist? Tourism Definition from the Tourist Perspective. Tourism Analysis, 17, pp.445-457.

[80] Zhou, K.Z., Li, J.J., Zhou, N., Su, C., 2008. Market Orientation, Job Satisfaction, Product Quality, and firm Performance: Evidence from China. Strategic Management Journal, 29(9), pp.985-1000. 